\title{
Are Pashtuns the Lost Tribe of Israel?
}

\author{
Zaman Stanizai
}

Department of Political Science, California State University Dominguez Hills, Carson, California 90747 USA

Zaman Stanizai is Professor of Political Science at California State University, Dominguez Hills and Professor of Mythological Studies at the Pacifica Graduate Institute in Santa Barbara, California. Dr. Stanizai has earned an MA degree in linguistics at the University of Washington in Seattle as a Fulbright scholar and he has earned a Ph.D. and MA degrees in political science at the University of Southern California. His recent research in political theory focuses on national and sub-national identities and the viability of third world nation-states encountering globalization. He has lectured widely on Islamic contributions to world civilization. 


\title{
Are Pashtuns the Lost Tribe of Israel?
}

\begin{abstract}
The recently resurfaced rumors propped up by certain Israeli circles that the Pashtuns are the lost tribe of Israel has given academic circles a lingering pause. Its biblical claims are anecdotal, its historical documentation is inconsistent, its geographic claims are incoherent, and its linguistic assertions are implausible. More importantly, the claim doesn't stand a chance of a DNA verification. Politically, the claim has hit a raw nerve in Afghanistan where the legitimacy of Pashtun power as an ethnic majority is challenged while in Pakistan the distinct Pashtun cultural identity is threatened. Amidst this hyped ethnolinguistic strife that threatens regional stability, the 'why now' of the resurfaced controversy is as unnerving as the 'why then' of its origins is disconcerting. This article examines the claim from historical, cultural, linguistic, and genetic perspectives as it explores the root causes of how the rumors may have started in the first place and the reasons for its persistence.
\end{abstract}

Keywords: Afghans; Afghanistan; Pashtun; Pathan; Indo-Iranian; Aryans; Delhi Sultanate; the Indus Valley; the Lost Tribes of Israel; Israel; Khazaria; Palestine; Jews; Zionism; Talmudic Jews; Ashkenaz;

\section{Introduction}

The Jewish people who had been dispersed around the world historically always aspired to make Aliyah, 'ascend' to the hilltops of Jerusalem. With politicized Judaism Aliyah became a fundamental component of Zionism, and its objective expanded from a return to Jerusalem to settling in all of Palestine/Israel. Towards the implementation of that objective, efforts are underway to identify the lost tribes of Israel anywhere in the world and facilitate their return. 
One such attempt is a genetic study funded by the government of Israel, claiming that the Pashtuns of Afghanistan and northern Pakistan are the lost tribes of Israel. This assertion that most likely came out of the rumor mills of $13^{\text {th }}$ century India has been ripe with controversies from the start, not only because academic circles consider the anecdotal claim as a historical myth, legend, or fiction at best, but also because there is no linguistic link between the Semitic Hebrew and the Indo-European Pashto that could thread the cultural core of the two communities. Not to mention the fact that the 'unintended' consequences of such a claim have intensified xenophobia in the current ethnocentric civil war in Afghanistan and the political strife in Pakistan.

Shalva Weil in her article, The Israelite Connections of the Taliban claims, for instance, that a certain Pashtun tribe, the Yosufzais, 'the Sons of Yosuf,' are the children of Joseph arguing that, "When I interviewed members of the Yusuf-Zai (sons of Joseph) tribe years ago in the orchards of Kashmir, they related their origins with pride."1 While many historicized fairytales with fictitious characters such as Qais Abdur Rashid have been spun by the rumor mills during the 13th-century TurcoPashtun rivalry in India, Yosufzai is actually an Arabized/Islamized form of the word

\footnotetext{
${ }^{1}$ Shalva Weil, The Israelite Connections of the Taliban - By Shalva Weil for ISN Insights. Africa News Analysis. 08/09/2011 (Online) https://www.africanewsanalysis.com/the-israelite-connections-of-thetaliban-by-shalva-weil-for-isn-insights/

Dr. Weil's views on this topic are also expressed in a video lecture titled, “ $R \& B$ : Dr. Shalva Weil on 'In Search of the Lost Ten Tribes" presented at the Root and Branch Association lecture in the Orthodox Union Israel Center in Jerusalem in 2016. Her reference to the Pashtuns is in minutes 6:30 - 9:50 (Online video): https://youtu.be/29QsMA63uxI
} 
Aspzai. The word as/asp as in Aspzai and its pre-Islamic version Aspasioi, referring to 'Yousufzai,' means horse and horsemanship and have traditionally symbolized wisdom, honor, and nobility. ${ }^{2}$

"Aspasioi, incidentally, is the tribe most frequently mentioned by Alexander's historians," according to Salman Rashid who believes that, "The asp became Yusuf (pronounced Esop by Pakhtuns) only after conversion to Islam and the need to invent a Muslim sire. The Aspzai thus became Esopzai - Yusufzai for the educated classes." 3

Shalva Weil may have gotten an inspiration or a hint from a claim she attributes to the first president of Israel, Itzchak Ben-Zvi, that "the Pashtun tribe Rabbani could be

${ }^{2}$ Incidentally, the cultural equivalent of Aspzai Pashtuns by geographic association is Afghans that have also derived from identical etymological roots. The Sanskrit Ashv, Ashvaka, the Pahlavi/Ashkani Apakan, and Awgaan in the Shahnamah, the Indian Avagana, and later Abkan/Abgan all reference and connote Afghans as horsemen and nobility. This association between the horse and wisdom or nobility is common in other cultures as well. The Arabic feras, 'horse' and feraasa(t), 'wisdom, perceptivity,' or for that matter the Prophet's ascension to heaven on the wings of a steed named burraq, 'shining light' implies metaphorically an ascension through wisdom and light. European languages exhibit a similar association between the horse and nobility and honor. The word chevalier, literally a horseman, in French connotes honor as symbolized in France's Legion d'honneur representing merit and excellence in wisdom. Caballero in Spanish means both a horseman and a gentleman. In English word knight as in knighthood symbolizes nobility and in the game of chess, it is represented by the horse-shaped chess piece. The double entendre in sir/sire, as an alteration of Latin senior that also means stallion.

3 Salman Rashid, Pakhtuns. Published in The Express Tribune, November 12 $2^{\text {th }}, 2011$. https://tribune.com.pk/story/290251/pakhtuns 
the lost Israelite tribe of Reuben; Shinwari could be Shimon; Daftani could be a corruption of Naftali; Jajani - Gad, Afridi - Ephraim, and so on." "4 Along the same line, she quotes Abraham Benjamin, a Jew from Herat in Afghanistan, saying that "According to the tradition current among the Afridis (one of the Pashtun sub-tribes), they are descendants of the Israelites, more particularly, the sons of Ephraim."5 In a parallel assertion the Beta.Moshiach.com seem to impose the names of the Ten Lost Tribes of Israel on similar-sounding Pashtun tribe names, "The Rabbani Tribe is really Reuben, the Shinware Tribe is Shimon, the Lewani Tribe is Levi, The Daftani Tribe is Naphtali, and the Jaji Tribe is Gad, and the Ashuri Tribe is Asher, The Yusefsai Tribe is

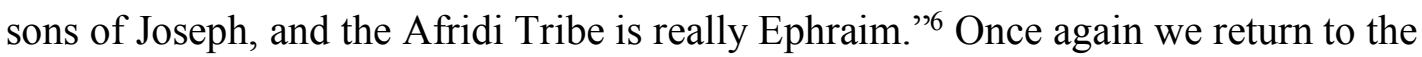
Greek sources:

"From the geographer Strabo $\left(1^{\text {st }}\right.$ century CE) we hear of two other startlingly long-lived names. He mentions Apratai and Shattagadai. His translator, John McCrindle, reminds us that Afridis, and indeed other Pakhtuns as well, have difficulty in pronouncing ' $\mathrm{f}$ ' sounds, turning them forever into ' $\mathrm{p}$ '. Apratai is, therefore, Strabo's rendering of Afridi exact to a turn."

\footnotetext{
${ }^{4}$ Ibid.

${ }^{5}$ Ibid.

${ }^{6}$ Beta.Moshiach. Pathans As the Descendants of the Lost Tribes of Israel. Online (Retrieved October 8, 2020): http://beta.moshiach.com/tribes/pakistan.html

7 Salman Rashid, Pakhtuns. Published in The Express Tribune, November 12 ${ }^{\text {th }}, 2011$. https://tribune.com.pk/story/290251/pakhtuns
} 
These claims and the supporting arguments they are based on are flawed for the following reasons:

1. They don't take into account the prevalence of Arabic names in Muslim communities throughout the world who adopt Qur'anic/Biblical names such as Adam, Ibrahim, Ismael, Yosuf, Sulaiman, Daud, Musa, Isa, etc. out of religious affinity and not necessarily any racial affiliation.

2. There seems to be an attempt to find a Pashtun name that resembles the name of a lost tribe of Israel with no regard for the Hebrew-Pashto sound patterns and with no knowledge of the cross-linguistic influences and code-switching, etymology, phonetic assimilation, or other diachronic changes these names/words may have gone through in the course of time.

3. The resemblances they seem to find or more likely wish to see are conveniently referred to as, "No less interesting and significant are the names of the tribes which bear [a] close resemblance to the Tribes of Israel." ${ }^{8}$ The proponents of these claims are not aware that the resemblances they find are not between biblical Hebrew and modern Pashtun tribe names, rather between Hebrew names and the often Arabized, Persianized, or Indianized forms of Pashtun tribe names:

- Take, for instance, the claim that "Jaji Tribe is Gad" or "Jajani - Gad." In Pashto, the voiced affricate /dz/ as in Dzadzai is often reduced to /j/ in Persian. So, when Pashtuns speak to non-Pashtuns through code-switching, the Pashto name Zazai would be commonly rendered as Jaji.

\footnotetext{
${ }^{8}$ Ibid.
} 
- Rabbani and Ashuri are not Pashto words or Pashtun tribe names. Both are Arabic words/names that could possibly be family or clan names that seem to conveniently serve the intended purpose.

- These claims are even more implausible considering that the Pashto language does not have the phoneme /f/, the key consonant in the names Daftani and Ephraim. ${ }^{9}$ The claim that "The Daftani Tribe is Naphtali" is not accurate. Similarly, Afridi is not a Pashto word, but the Persianized form of the Pashto name Apraydai; and Apraydai cannot be etymologically or phonologically linked to Ephraim by any stretch of the imagination. ${ }^{10}$ This is even more relevant to the case of Afghan/Afghana/Afaaghena which will be discussed later.

Thus, the basic principles of morphophonology, the branch of linguistics that studies the interaction between morphological and phonological or phonetic processes that help linguists predict diachronic changes in the sound pattern of a language, simply cannot support such assertions. Therefore, they are mere conjectures and forced

\footnotetext{
${ }^{9}$ Yulia Egorova and Shahid Perwez, The Children of Ephraim: being Jewish in Andhra. Anthropology Today Vol. 26, No. 5, December 2010.

${ }^{10}$ The incentive to get settled in Israel has turned up claimants of Jewish ancestry in all sorts of places. At the time the Pashtun Afridis were claimed to be the "Sons of Ephraim,' a small Telugu speaking group, the Bene Ephraim (meaning "Sons of Ephraim" in Hebrew) also claimed ancestry from Ephraim. Later investigations revealed that the "Telugu Jews" observance of modern Judaism dated back only to 1981 .

https://www.youtubez.com/index.php?q=aHR0cDovL3dIYi5hcmNoaXZILm9yZy93ZZWIvMjAx MTA2MTAwNDE5MzYvaHR0cDovL2VuLndpa2IwZWRpYS5vcmcvd2IraS9CZW5IX0VwaHJ haW0
} 
interpretations on far-fetched similarities of sound systems that are not retraceable to Hebrew.

If the claim had been made only on the basis of phonological changes, the argument could've ended right there, but the sophistry of ideology-driven arguments defy convention and stand only on conviction. That's why this issue has to be analyzed more thoroughly to see whether the present of the two people can be traced back to common ancestry as claimed.

Pashtuns/Afghans and Jews/the lost tribes of Israel have inhabited lands far apart from one another geographically, they speak languages that belong to distinctively different language families, their paths haven't crossed in the annals of recorded history, and they are very different in their ethnogenesis. Then how and where did the rumors of their shared ancestry all begin? What accounts for the persistence of these rumors? What contributed to their dissemination? And most of all, what difference does it make if these rumors are true or not?

\section{Authenticating the Inauthentic}

This research identifies the sources of these rumors, the possible reasons and motivations for creating them, and the circumstances contributing to the dissemination of these rumors through intent or neglect. These can be summarized as the indiscretion in the interchangeable use of the words Afaaghena, Afghana, Afghan, and Pashtun or Pathan that contributed to the ethnic misidentifications and linguistic misinterpretations disseminated by the rumor mills and yellow journalism of $13^{\text {th }}$ century India and gained further notoriety during the colonial period until they came back full circle to the region 
becoming part and parcel of the present-day political/ideological entanglements. We will discuss this outlined chain of cause and effect in the following order:

(1) the deliberate misreading of the word 'Afaaghena,' (Arabic broken plural of the word Afghan without the soft vowel diacritics) as the equivalent of the biblical 'Afghana.'

(2) the incidental synonymity between the geographic identity of the Afghans and the ethnic identity of the Pashtuns that led to the interchangeable use of the two terms that persist to this day.

(3) lending undeserved credence to the written word and the presumption of $21^{\text {st }}$-century objectivity to folktales, epics, and historical narratives of the story-telling culture of $13^{\text {th }}$-century India.

(4) the timing of the abundant availability of paper that disseminated the imaginative stories even faster after the $13^{\text {th }}$ century.

(5) the eagerness of the colonial era European writers who were ready to portray the exotic East in exaggerated terms to their Western readers.

(6) the missionary zeal of the post-enlightenment era writers who tried to validate scriptural hearsay through the anecdotal accounts of the distant East to make them appear 'historical' and 'scientific.'

\section{Historicizing the Scriptural}

Where does the idea of the lost tribes of Israel originate? The Bible speaks of the Ten Lost Tribes of Israel that were exiled by Shalmaneser V, the king of Assyria who 
subjugated ancient Israel during his reign $726-721 \mathrm{BCE}^{11}$. The Encyclopædia Britannica, however, says that "None of his historical records survive," other than that he has been linked "with Tiglath-pileser III, whose son he may have been." 12 Like many of the biblical personalities, what is biblical may not necessarily be historical.

The Jewish tribes were exiled beyond the mythical Sambation or Sabbatical ( $\Sigma \alpha \beta \beta \alpha \tau \iota \kappa o v)$ River that rages with rapids and throws up stones six days a week, except on Shabbat when the river stops flowing. Other accounts say that the river consists entirely of stone, sand, and flame. Some have referred to it as a fountain or an active volcano while others have described it as a legendary river "whose foaming waters rise high up into the sky a wall of fire and smoke that is impossible to pass through."13

The whole idea of the myth is that the lost tribe of Israel is completely surrounded by a river, which flows with rocks for six days a week except on Shabbat. So, the Jews can't ever leave, for by doing so, Shabbat would be desecrated. That there existed a river that adhered to a strict Jewish law is obviously a myth and any attempt to dress up scriptural anecdotal accounts in scientific jargon to make them historically credible is an exercise in futility.

Equally flawed, and very critical to this argument, is the location of the Sambation River that is given no particular attributes except for a few $1^{\text {st }}$-century

\footnotetext{
11 The Bible 2: Kings 17:5-23. Bible verses for: 'Lost' Ten Tribes of Israel. This is further elaborated on by Charles Whitaker, “The Scattering of Ten-Tribed Israel.” Forerunner, December 2004.

12 The Encyclopædia Britannica https://www.britannica.com/search?query=Tiglath-pileser+III

${ }^{13}$ Moses Rosen, "The Recipe” (published as an epilogue to The Face of Survival) 1987.
} 
conjectures by Pliny the Elder who identifies it as a river in Judaea that dries up every Shabbat and one by Josephus who locates it between $\mathrm{Arka}^{14}$, Lebanon and Raphanaea in Upper Syria. $^{15}$

Nahmanides identifies the Sambation with the Guzana River mentioned in II Kings, located in Medes. ${ }^{16}$ Encyclopedia Judaica suggests the Medes "the mountainous area of northwestern Iran and the northeastern and eastern region of Mesopotamia located in the Kermanshah-Hamadan (Ecbatana) region" where these tribes may have settled around 1100 to $1000 \mathrm{BCE} \cdot{ }^{17}$ Between the dates of the biblical account and that given by Encyclopedia Judaica of the lost tribes of Israel, there is a discrepancy of 400 years.

Avraham Yari says that "Obadiah ben Abraham writes that he was informed by Adeni Jews in Jerusalem, that they had heard from Muslim merchants that the (Sambation) river was located about fifty-days' walking distance from their place (emphasis added) as one journeys through the desert."18 The description of 'fifty-days' walking distance through the desert from Aden on the edge of the Arabian Peninsula from whence one could only walk in a north-westerly direction points to Lebanon,

${ }^{14}$ Arqa (Arabic: عرقا) (Phoenician: Irqata; Hebrew: ערקת, 'Arqat in the Bible) is near Miniara in Akkar Governorate, Lebanon, $22 \mathrm{~km}$ northeast of Tripoli, near the coast.

${ }^{15}$ Rabbi Ovadiah of Bartenura, Pathway to Jerusalem. CIS, 1992.pg. 68.

${ }^{16}$ ibid.

${ }^{17}$ S. David Sperling (2 $2^{\text {nd }}$ ed.), Medes and Media. Encyclopaedia Judaica Jewish Virtual Library (Online) http://www.jewishvirtuallibrary.org/medes-and-media

${ }^{18}$ Avraham Yari, Igros Eretz Yisroel (Letters of the Land of Israel), in the "Letter of Rabbi Obadiah di Bertinora from Jerusalem to his Brother," written in 1489, Tel-Aviv. 1943: p. 140. 
Upper Syria, Mesopotamia, Hamadan and possibly Kurdistan, but certainly not to Afghanistan or Pakistan.

The assumption that the north-westerly migration pattern from Aden would have somehow veered off in an easterly direction from Jerusalem to Afghanistan contradicts every hypothesis on recorded migration patterns in southwest Asia. Virtually every Indo-Aryan and Iranian migration model consistently points to a north-to-south scenario. These include paths of seasonal migrations, climate-related mass migrations, as well as more recent military campaigns that have at times, depended on these migratory pastoral communities for recruitment:

The earliest indication of this south-east-bound migration route dates back to 7000 BCE during the spreading of agriculture. Subsequently, the Kurgan hypothesis dates the scheme of the Aryans spread from west Asia from ca. 4000 to 1000 BCE. ${ }^{19}$ The Hutchinson History of the Nations illustration shows Aryans entering India from the northwest around $3500 \mathrm{BCE}^{20}$ The Sintashta culture that developed on the Central Asian steppes confirms the above and dates these migration patterns between 2100 $1800 \mathrm{BCE} .{ }^{21}$ The Bactria-Margiana culture in its southbound migration splits off the Indo-Aryans from the Iranians around 1800-1600 BCE. ${ }^{22}$ The early Vedic period

\footnotetext{
${ }^{19}$ Christopher I. Beckwith Empires of the Silk Road, Oxford University Press. 2009: p.30.

${ }^{20}$ The Forenoon of Life - Aryans entering India, 3500 B.C., illustration from Hutchinson's History of the Nations, c. 1910 .

${ }^{21}$ David W. Anthony, The Lost. World of Old Europe, 2009: p. 390 (fig. 15.9), 405-411.

${ }^{22}$ David W. Anthony, The Horse the Wheel and Language. 2007: p. 408.
} 
migrations along that same route are dated between $1700-1100$ BCE. ${ }^{23}$ And lastly the Yuezhi, an Indo-European Caucasian people of possible Tocharian stock, migrated south between $176 \mathrm{BCE}$ to $30 \mathrm{CE} .{ }^{24}$ Violatti sums it up this way: "By $1500 \mathrm{BCE}$ the Aryans migrated into the Indian subcontinent. Coming from Central Asia, this large group of nomadic cattle herders crossed the Hindu Kush Mountains and came in contact with the Indus Valley Civilization."25

Venkataramakrishnan validates the migration route and concludes that, "around the 2nd millennium BCE, Steppe pastoralists moved south towards the subcontinent encountering the Indus Valley... afterwards... some of the Indus Valley population moves further south," 26 as shown in his accompanying map below:

${ }^{23}$ J. E. Schwartzberg, A Historical Atlas of South Asia: University of Oxford Press Staal, F. (2008) 1992.

${ }^{24}$ Christopher I. Beckwith 2009: pp. 380-383.

${ }^{25}$ Cristian Violatti, Aryan, The Ancient History Encyclopedia. Published 06 April 2018. Retrieved 2020/01/05.

${ }^{26}$ Rohan Venkataramakrishnan, Who was here first? A new study explains the origins of ancient Indians. QuartzIndia. April 2, 2018. Retrieved January 7, 2020. 


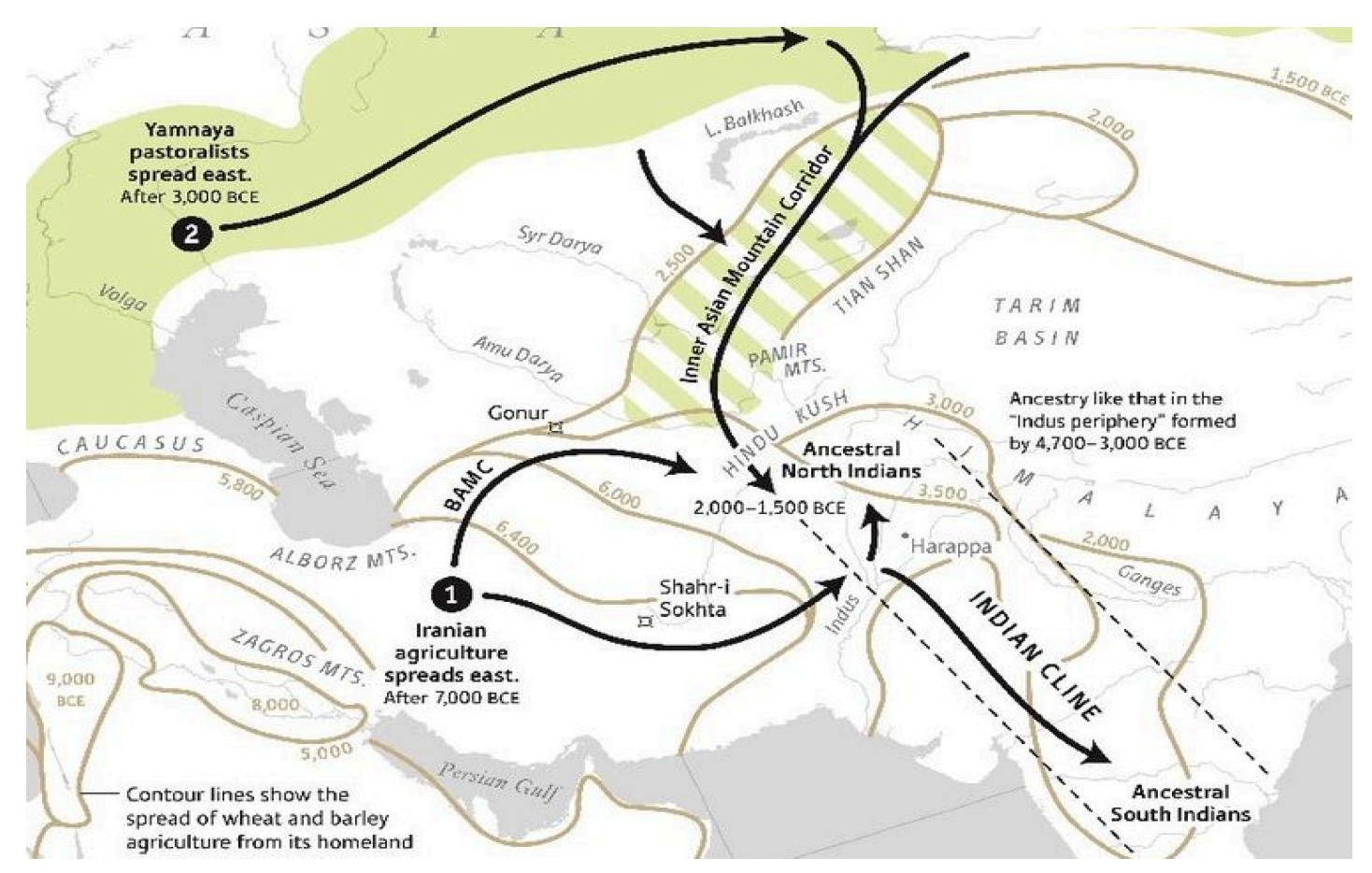

The Early Aryan Migration to the Vedic Period into India by Venkataramakrishnan

From the historical evidence as this map suggests, we can conclude that the only east-bound migration from anywhere near the Zagros mountain region was around 7000 $\mathrm{BCE}$. If by any chance and for any reason 5000 years later the lost tribes of Israel traveled farther east of Medes, to the vicinity of the present-day Pashtun lands, they would've inevitably walked right into this well-traversed south-bound migratory path that would've swept them along the way to the Indian subcontinent.

There are proponents of the "Out of India" theory or the "Indian Urheimat" theory believing that the Indo-European language family originated in Northern India and radiated to their present locations. This is argued to have taken place in the context 
of "an unbroken tradition that goes back to the earliest period of the Sindhu-Sarasvati (or Indus) tradition (7000 or $8000 \mathrm{BC}) . " 27$

We do not dispute the valid points each of the two theories offer and they do not contradict our argument which is based on the migration pattern of the pastoral Central Asians who migrated south more recently in order to avoid droughts and other environmental calamities. This is certainly evidenced by the shifts in population movement between Central Asian and the Indian subcontinent.

\section{Pashtun Ethnogenesis}

Regarding Pashtun ethnogenesis, "historians have come across references to various ancient peoples called Pakthas (Pactyans) between the $2^{\text {nd }}$ and the $1^{\text {st }}$ millennia BCE who may be their early ancestors." 28 The Greek historian Herodotus mentions a people called Pactyan living on the eastern frontier of the Achaemenid Arachosia Satrapy as early as the 1 st millennium BCE. ${ }^{29}$ As the map of the Median Empire below shows the Pactyans territory in what is now Afghanistan and Pakistan ${ }^{30}$

${ }^{27}$ Kak Subhash, "On the Chronology of Ancient India." Indian Journal of History of Science. 1987 (22): 222-234. Archived from the original (PDF) on 2015-01-22. Retrieved Jan 2015.

${ }^{28}$ Samir Nath, Dictionary of Vedanta. Sarup \& Sons. 2002: p. 273. Retrieved 10 September 2010.

${ }^{29}$ George Rawlinson (Trans.), "The History of Herodotus Chapter 7, Written 440 B.C.E. Piney.com. Retrieved 2012-09-21.

${ }^{30}$ Emerson Kent. Com. History for the Relaxed Historian, http://www.emersonkent.com/map archive/oriental empires 600 bc.htm Retrieved 2020-01-05. 


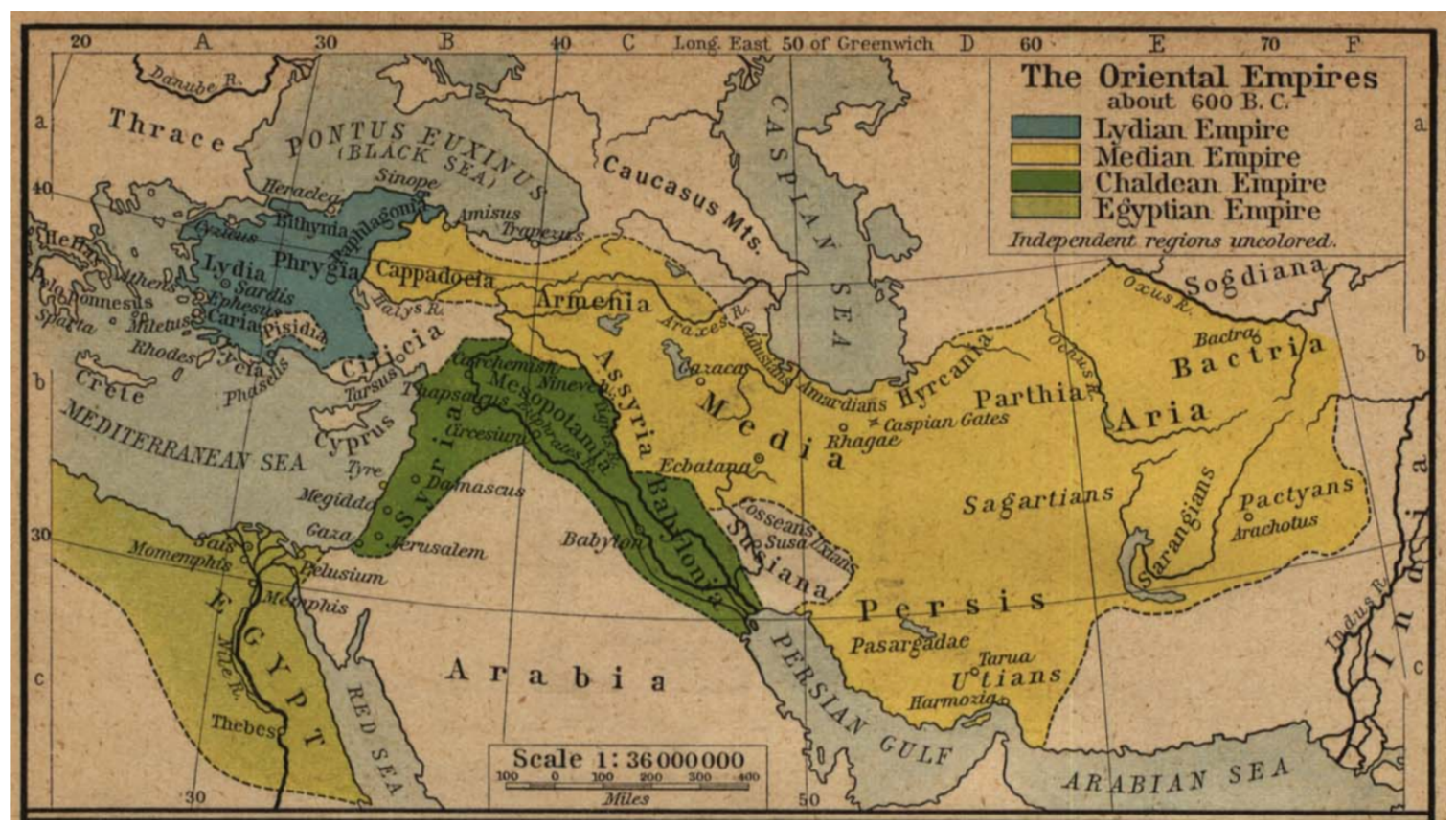

Sanskrit and Greek sources also reference an ancient people called Pakthas living in the region which includes south-eastern Afghanistan and the northern parts of Pakistan. According to Mandala 7 of the Rigveda, "The Pakthas were one of the tribes that fought against Sudas in the Dasarajna the Battle of the Ten Kings (dāśarājñá). ${ }^{31}$ Also, "The Pakthas lived in the hills from which the Kruma (Kurram Valley) originates." 32 Zimmer locates them in present-day eastern Afghanistan, identifying them with the modern Pakthun. ${ }^{33}$

\section{Default Synonymity: Afghans vs Pashtuns}

${ }^{31}$ D. R. Bhandarkar, "Mandala 7 of the Rigveda Some Aspects of Ancient Indian Culture" RV 7.18.7) p.2.

${ }^{32}$ Ahmad Hasan Dani, Timargarha and Gandhara Grave Culture. Ancient Pakistan: Volume 3, University of Peshawar. Dept. of Archaeology - 1967, Page 23.

${ }^{33}$ Heinrich Zimmer quoted in Ahmad Hasan Dani, Timargarha and Gandhara Grave Culture. 
The words Pashtun and Afghan are not etymologically related. The former is an ethnolinguistic identity while the latter is a geopolitical descriptive. The likely reason for the synonymous interchangeable use of Pashtuns and Afghan(istan) is the overlapping commonalities between the cultural traits of the people as brave, resolute and freedom-loving and the attributes of the land as the unconquerable 'graveyard of the empires.'

In respect to the subject matter at hand, however, there is a fundamental methodology problem in the interchangeable use of the word Afghan as an outside identification and the word Pashtun as self-identification. Overlooking the critical distinction between Afghan and Pashtun and using the two words as a single unit of analysis has led to grave misunderstandings, deliberately or otherwise, namely that Afghans are the descendants of Afghana or that Pashtuns don't have a history.

Hamid Naweed, a prominent Afghan archaeologist, believes that etymologically the word Afghan comes from Aspagana, connoting the meaning "cavalier" and is derived from the Sanskrit, Asva, or Asvaka, a horse, and shows that their country, the region between the Indus and the Hindukush, must have been noted in ancient times, as it is at the present day, for its superior breed of horses. In agreement with J.W. McCrindle, E. Reclus, Christian Lassen, and Alexander Cunningham, Naweed believes that the name Afghan refers to the inhabitants of the region rather than an ethnic group. ${ }^{34}$ According to the late Professor Abdul Hai Habibi, Varaha Mihira (505-587 $\mathrm{CE}$ ) in verses 11, 16, 31, and 61 of his book Bahrita Sanhita mentions the word Avagana which he believe is a variant of the word Afghan. ${ }^{35}$ The Chinese pilgrim

\footnotetext{
34 Hamid Naweed, Art Through the Ages in Afghanistan. 2018. passim. (Cf. footnote number 2)

35 Abdul Hai Habibi, “Afghan and Afghanistan.” Afghanistan, VOL. XXII No.2, Summer 1348 (1969).
} 
Hsuen Tsang, arriving in the same geographic region on June 20, 644 CE, names the people of the region as O-Po-Kien in his travelogue that sounds very similar to the word 阿富汗 (Áfùhàn), ‘Afghan’ in modern Chinese. Many historians including Cunningham believe O-Po-Kien to be the equivalent of Awa-gan (Afghan). ${ }^{36}$ Incidentally, regional languages that are least Arabized and do not have the phoneme /f/ such as Turkmen and Kyrgyz also pronounce the word Afghan as Owgan, and Oogan respectively.

According to Professor Habibi, the most likely proto-form of the word Afghan appears in the Naqsh-e Rustam inscription in Persepolis dating back to the reign of Shahpour, I (260-273 CE) that mentions in Pahlavi Ashkani and Greek languages the words Vindaparn Abgan Rismaud as the men of distinction. ${ }^{37}$ Later Shahpour, III (309$379 \mathrm{CE}$ ) is honored as Apakan, ${ }^{38}$ Firdausi in his Shahnamah has numerous references to names that could be the intermediate forms of Afghan:

Their commander was Qaran Kawgaan

And generals Sheroi and Awgaan.

(Shahnamah I-110)

The mighty soldiers had gathered around the castle,

Armed with golden cudgels and golden helmets,

Their commander was Qaran Kawgaan,

\footnotetext{
${ }^{36}$ Sir Alexander Cunningham, The Ancient Geography of India 1871: Page 89.

${ }^{37}$ Abdul Hai Habibi, Archeological Recollections, Printed in Shiraz in 1959: Vol. IV, after page 181.

${ }^{38}$ Abdul Hai Habibi, "Afghan and Afghanistan". 1969. alamahabibi.com. Retrieved 2010-10-24.
} 
Led by the valiant general, Awgaan".

$$
(\text { Shahnamah I-116) })^{39}
$$

In all these records the word Abgan, Apakan, or Awgaan connote identical meanings of chivalry, rectitude, nobility or an esteemed line of descent that correspond to Naweed's description of Afghans as chivalrous horsemen. ${ }^{40}$

The etymological changes in the word Afghan in the pre-Islamic period would have followed change patterns that comply with phonological norms as follows:

Asvakan (Sanskrit) Assakenoi=horsemen -> Ashvakas (Indo-Iranian) and possibly Avagana (Indian) to Abkan/Apgan and Apakan (Pahlavi/Ashkani).

\section{Switching Cognates: Afaaghena vs Afghana (فغانهه - افاغن)}

The Arabization of the local languages during the Islamic period brought about phonetic as well as grammatic changes in cognate words: Accommodating the consonantal shifts in the Arabic sound system that lacks the phonemes $/ \mathrm{p} /$ and $/ \mathrm{g} /$ are

${ }^{39}$ Arthur George (Trans.). The Shahnama of Firdausi. The Persian Book of Kings, by Abolqasem Firdausi. 1010.

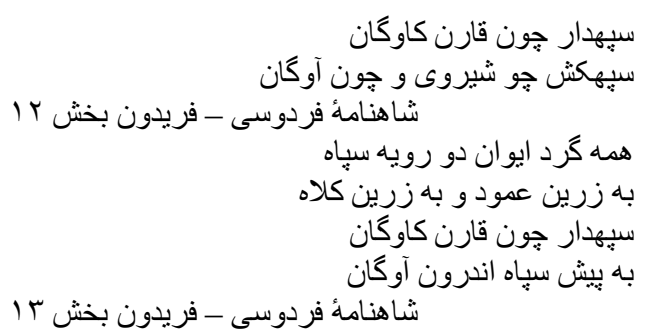

${ }^{40}$ Scottish Geographical Magazine, 1999, p 275, Royal Scottish Geographical Society. 
consistently changed to /f/ and /gh/ respectively rendering, for instance, Apgan as Afghan. $^{41}$

Grammatical constructs were other components of the Arabization of local languages. For instance, the jam' munkasar, or the broken plural rule in Arabic that uses inverted inter-fixes, instead of suffixes, were commonly used. This rule will render the singular of the word Afghan into Afaaghena in its plural form that can be easily mistaken for the biblical 'Afghana.'

This is where the problem begins - with the Arabization of written language forms in the literature of the Islamic period. The oldest of these books is Hudood-ul 'Alam written in $993 \mathrm{CE}$ by an anonymous author. ${ }^{42}$ In this book, the word Apgan is used in its Arabized singular form as Afghan and in the broken Arabic plural form as Afaaghena. Mohammad Qasim Firishta discusses the Afghan and Awgan tribes distinctively and Ibn-e Asir has used the older form of Abgan. Most of the other writers, however, have used the Arabized and 'conventionalized' form of Hudood-ul 'Alam, rendering it a standard. These include Mohammed bin Abdul Jabbar Utbi in Tarikh-e Yemeni, Fakhr-i-Mudabir in Adab-ul-Harb, Qazi Menhaj Seraj in Tabakat-e Nasseri, and Hamdullah Mustufi in Tarekh-e Guzida.

${ }^{41}$ An additional contrastive element in this controversy is that the word Afghan is not a Pashto word and some Pashtuns have trouble pronouncing the word Afghan since Pashto does not have the phoneme /f/. Similarly, some Arabs have trouble pronouncing the word Pashtun because Arabic does not have the phoneme /p/. This divergence hints phonologically at the mutually exclusive implications of the two words, Afghan and Pashtun.

${ }^{42}$ Minorsky gives the credit of its authorship to Ash'iya Ibn Fariqun of Jouzjan elsewhere the work has been attributed to Abu Yousuf Peshawari. 
European writers conveniently, but erroneously, linked the Arabized plural of Afaaghena to the biblical Afghana. Had Hudood-ul 'Alam not used the Arabized forms and the Arabic conventions, there would most probably have been little chance of linking Afghan to Afghana or the lost tribe of Israel.

\section{From Rumor Mills to Paper Mills}

Popular culture in $13^{\text {th }}$-century India thrived on stories of jinn, ghouls, sorcerers, and magicians. This genre of story-telling exemplified by Kalila wa Demna and the Lion King were the cultural counterparts of the Arabian Nights and precursors to modern novels. ${ }^{43}$

Deliberate exaggerations in these stories were more important than the accuracy of the claims and assertions they made. In order to make these stories sound more believable, they were often embellished by intermixing legends with the stories of real people and places. Storytellers with a hero-worshiping mindset recorded the hearsay of the popular culture in historical voice. On the one hand, the writers were not trained historiographers to base their claims on research and documentation. All that was missing was a convenient political villain to pick on.

In June 1290 the first Khaljī Sultan, Jalāl al-Dīn Fīrūz Khaljī, was established by a noble faction as the new ruler of the Delhi Sultanate after the collapse of the last feeble Slave king, Kay-Qubādh. But since the majority of the ruling class Indian Muslims at the time were of Turkic origin, they did not like the new rulers who were

\footnotetext{
${ }^{43}$ Many of the stories that ended up in The Arabian Nights had their roots in Indian folklore such as the Sanskrit fables, Panchatantra, Baital Pachisi, Jataka Tales, and other Buddhist stories. Richard F Burton. (2002). Vikram and the Vampire Or Tales of Hindu Devilry p. xi. Adamant Media Corporation.
} 
Pashtuns/Afghans. Encyclopaedia Britannica writes, "Jalāl al-Dīn was already elderly, and for a time he was so unpopular-because his tribe was thought to be Afghan - that he dared not enter the capital.",44

The Turco-Pashtun rivalry has left a lasting mark on the culture of northern India since. Even today, the resentment of Pashtuns is evident in India's modern-day story-telling culture - the movie industry. ${ }^{45}$ One of the reasons could be that the Turkic tribes assimilated quickly and got accepted into the Indian society, but the Pashtuns retained their ethnic identity much longer as they stayed in touch with other Pashtun communities in the highlands of Afghanistan through seasonal migration and trade. This made the word Pashtun synonymous with the word Afghan. The Arabized literati employed the Arabic plural rule turning Afghan to Afaaghena - that must have been equated to the biblical Afghana after that. Incidentally, the first accounts of Pashtuns being the lost tribe of Israel also surfaced and gained notoriety at this time.

In 1333, the famous Ibn Battuta, for instance, wrote about Afghans: "Their principal mountain is called Kuh Sulayman. It is told that the prophet Sulayman [Solomon] ascended this mountain and having looked out over India, which was then covered with darkness, returned without entering it."46

\footnotetext{
${ }^{44}$ Khaljī dynasty, Encyclopaedia Britannica https://www.britannica.com/topic/Khalji-dynasty

${ }^{45}$ In Gandhi, the pivotal role of the Pashtun Ghaffar Khan a.k.a. 'the Frontier Gandhi' was reduced to a mere few-second glimpse. The vilification of the Pashtun Sultan Allaudin Khilji at the expense of his Hindu opponent Ratan Singh in Padmaavat, a 2018 release, can be measured by the $\$ 81$ million box office revenue in the first few weeks of its release (Ref. Noor Ahmad Khalidi. Khilji Dynasty.

Downloaded 13 January 2019

${ }^{46}$ Ibn Battuta, Travels in Asia and Africa, 1325-1354 Routledge. (reprint, illustrated ed.) 2004: p. 180. Retrieved 2010-09-10.
} 
If this sounds like a fairytale, it is - here is why. The other-worldly feats of King Solomon had been mythified in the many legends of the region for centuries. With the advent of Islam, Prophet Sulaiman looms even larger in Islamic folk and mystical literature. His ability to harness the wind, traverse the globe on flying carpets, and land on high mountains led to the naming of several mountains in the region after him, written variously in Persian, as Kuh Sulayman, Koh-e Sulaiman, Sulimany mountains or Takht-i Sulaiman. The name Takht-i-Suleiman, 'the Throne of Solomon' had been assigned to several flat-topped mountains throughout the Middle East and Central Asia, including Takht-i-Suleiman in Khyber Pakhtunkhwa, Pakistan; Sulayman Mountain, Kyrgyzstan; Takht-e Sulayman (Qasr-e Abu-Nasr), Shiraz, Iran; and Takht-e Soleymān, West Azerbaijan, Iran. ${ }^{47}$

Obviously, any association with Solomon was illusory and unreal attributing either an imaginary or a fallacious existence to a place or a people. The Turco-Pashtun rivalry in Delhi Sultanate vilified Pashtuns who were otherized as a people from nowhere, i.e. Koh-e Sulaiman, which was now treated as some faraway geographic reality. Nobody questioned the logic as to why would the Pashtuns suddenly rename their own mountains in Persian if for centuries they've been calling their mountain ranges and mountain peaks in Pashto from south to north as Zarghun Ghar, Speen Ghar, De Kassay Ghar, and De Baba Ghar.

It seems that people lent more credence to the written word than to the accuracy of the information that was written. Paper manufacturing that was introduced to India at

\footnotetext{
47 Takht-i-Suleiman, Wikipedia. https://en.wikipedia.org/wiki/Takht-i-Suleiman
} 
this time $\mathrm{e}^{48}$ further contributed to wide-scale dissemination of these historicized fairytales throughout the region.

With the passage of time, legends were padded with more heroic personalities of the popular culture. Muhammad Qāsim Firishta wrote: "He [Khalid bin Abdullah son of Khalid bin Walid] retired... into the Sulaiman Mountains, situated between Multan and Peshawar, where he... gave his daughter in marriage to one of the Afghan chiefs.... From this marriage, many children were born, among whom were two sons famous in history. The one Lodhi, the other Sur; who each, subsequently, became head of the tribes which to this day bear their name." 49 Note how all Pashtuns throughout the region are conveniently reduced to the Lodhi and the Sur, the two royal dynasties relevant to political life in northern India.

Firishta later quotes from Mutla-ul-Anwar, that: "The Afghans are Copts of the race of the Pharaohs; and that when the prophet Moses got the better of that infidel who was overwhelmed in the Red Sea, many of the Copts became converts to the Jewish faith; but others... came to India, and eventually settled in the Sulimany mountains, where they bore the name of Afghans." 50

As most of these court historians were commissioned to write for the pleasure of their patrons, their standard of objectivity must be questioned. Contemporary scholars such as Peter Jackson questions the credibility of Firishta's work in Tarikh that it has not only relied heavily upon the works of others instead of writing as a first-hand

\footnotetext{
${ }^{48}$ Steven R. Fischer, A History of Writing, London: Reaction Books, 2004: p. 264.

${ }^{49}$ Muhammad Qāsim Hindū Šāh Astarābādī Firištah, History of the Mohamedan Power in India 15601620.

${ }^{50}$ Muhammad Qāsim Hindū Šāh Astarābādī Firištah, History Of The Mohamedan Power In India 15601620.
} 
account of events but that "at places in the Tarikh he is suspected of having relied upon legends and his own imagination." 51 T. N. Devare describes another of Firishta's accounts as "the only source for a fabricated story asserting the Ottoman origin of Yusuf Adil Shah." 52 With this standard of historiography should one expect the Pashtuns to have fared any better?

Another twist was added to this drama in the transitional turbulent times of $16^{\text {th }}$ century India when the Pashtun-dominated Delhi Sultanate was on the decline and the Mughal rise to power was imminent. The Mughals vilified their rival Pashtuns by popularizing the Pathan as a pejorative that lingered as disparaging cultural stereotypes. ${ }^{53}$ Even today, Indian mothers depict Pathans as monsters when they put their children to bed, they scare them, telling them: 'If you don't sleep, the Pathan will come and get you. ${ }^{54}$ — a derision and contempt heretofore reserved for Jews. If anything, this scorn and hatred may be the only common denominator between the Jews and the Pathans/Afghans in India - the two groups that resisted assimilation and were considered outsiders. There is no record or reference prior to this period that connects the Jews and the Pathans that had now become synonymous with Afghans.

\footnotetext{
${ }^{51}$ Peter Jackson, The Delhi Sultanate. Cambridge University Press. Retrieved 2009-02-20.

${ }^{52}$ T. N. Devare, A Short History of Persian Literature; at the Bahmani, the Adilshahi, and the Qutbshahi Courts. Poona: S. Devare, 1961. T. N. Devare 67 fn2, 272). Chisholm.

53 Bollywood movie stars of Pashtun descent like Mohammad Yusuf Khan whom the Bollywood Hungama. (Retrieved 7 August 2011) considers "the most admired movie star of Hindi cinema" was asked by Devika Rani owner of Bombay Talkies in 1943 to adopt Dilip Kumar, a Hindu name, to avoid being identified as a Pashtun. That trend of the Bollywood Golden Age changed only recently with the rise of the new generation of Pashtun actors such as Shah Rukh Khan and the Khans of Bollywood. 54 'Pathan ajayega.'
} 
With the passage of time, the names of notable biblical personalities and historical heroes were added to the anecdotal to make them sound more credible. The conventionalized hearsay, with the tacit approval of the politically empowered, eventually made it, by neglect or default, to the pages of Mughal-era yellow journalism and 'historiography.' The power of the written word gave this street jargon 'legitimacy.' The earliest of these stories is Khan-e-Jahan Lodhi's Maghzan-e-Afghani, compiled in the reign of Mughal Emperor Jahangir in the 16th century. Subsequently, Bakhtawar Khan describes the journeys of the Pashtuns from the Holy Land to Ghor, Ghazni, and Kabul in Mirat-ul- 'Alam, 'The Mirror of the World,' and the grapevine of Rahmat bin Shah Alam, in Khulasat-ul-Ansab. Embellished variations of these stories get told and retold in Fareed-ud-Din Ahmad in Risala-i-Ansab-i-Afghana [sic], Nimat Allah alHarawi in Tarikh-i-Afghana [sic], 'History of the Afghans' (translated by Bernard Dorn in 1829), the 1770 work of Muhammad Zadeek Tarikh-i-Hafiz Rahmatkhani, culminating in the 1899 book of Mirza Ghulam Ahmad, founder of the Ahmadiyya Muslim Community, titled 'Jesus in India.' These books were harping on the gossip without verifying the accuracy of their claims; they merely authenticated the inauthentic. They not only used Pashtuns and Afghans interchangeably but as Sir Olaf Caroe writes, "The truth is that Muslim commentators of the seventeenth and eighteenth centuries were not well up in the history of the Hebrews. They make no distinction between Israel and Judah, and do not seem even to be aware that there were two captivities." 55

As the interchangeable use of the words Afghan and Pashtun became a norm, the Pashtuns themselves began to equate Afghan with Pashtun as a source of pride.

\footnotetext{
${ }^{55}$ Sir Olaf Caroe, The Pathans: 550 B.C. - A.D. 1957. Oxford University Press, 1958: Page 5.
} 
Nationalist movements since the early $16^{\text {th }}$ century found it convenient to forge a national identity from the ethnic strands by fusing the two identities for political cohesion. Here the great $17^{\text {th }}$-century Pashtun poet, Khushal Khan Khattak, encapsulates this concept:

"Pull out your sword and slay anyone, that says Pashtun and Afghan are not one!

Arabs know this and so do Romans:

Afghans are Pashtuns, Pashtuns are Afghans. ${ }^{56}$

\section{The Colonial Trail of Telltales}

European writers of dubious authoritative scholarship gave further notoriety to this hearsay and tried to justify their claims through these books for their Western readers. Making a mountain out of a molehill, these writers fell victims to the gravitational pull of their own cultural proclivities by linking eponymous ancestral Pashtun names with Semitic roots such as Slaimankhail, 'the People of Solomon,' Yosufzai, 'the Sons of Joseph,' Musakhail, 'the People of Moses,' and Isakhail, 'the People of Jesus' to the Biblical/Hebrew narratives instead of their Qur'anic/Arabic origins. By that analogy, Muhammadzai, the royal dynasty of Afghanistan, ruling between 1826-1973, would certainly become 'the Sons of Muhammad.'

This is where the European writers' ignorance of the Pashtun history falls in the trappings of the Muslim commentators' lack of Hebrew history - the blind leading the blind. Sir Alexander Burnes, the first British Envoy to the Court of Kabul in 1837 claims that when he questioned King Dost Mohammad Khan about the descent of the

${ }^{56}$ C Biddulph, (Trans.). Afghan Poetry of the 17th Century: Selections from the Poems of Khushal Khan Khattak, "Extract from "Passion of the Afghan" by Khushal Khan Khattak.” London, 1890. 
Pashtuns from the Israelites, the King replied that "his people had no doubt of that, though they repudiated the idea of being Jews." ${ }^{57}$ A claim of equally suspect authenticity tells of an anecdotal account of the presentation of a Hebrew Bible by the head of the Yosufzai Pashtuns to Nadir Shah Afshar during his $18^{\text {th }}$-century military campaign. ${ }^{58}$

Burnes writes about the Pashtuns: "They say that Nebuchadnezzar, after the overthrow of Israel, transplanted them into the towns of Ghore near Bamean and that they were called after their Chief Afghan they say that they lived as Israelites till Khalid summoned them in the first century of the Muhammadans. Having precisely stated the traditions and history of the Afghans I see no good reason for discrediting them." (emphasis added). ${ }^{59}$

Henry George Raverty writes, “Afghana is settled by King Solomon himself in the Sulimani mountains; there is nothing about Nebuchadnezzar or Ghur. The historian Firishta says he had read that the Pashtuns were descended from Copts of the race of Pharaoh." Raverty further argues that "the Achaemenid king Cyrus, would've sent the Jews to the mountains of Ghor as a punishment. (emphasis added). ${ }^{60}$

Elphinstone, as quoted in Caroe, claims: "As regards the Ghor immigrants it is known that ten of the twelve tribes remained in the east after their brethren's return to Judea, and the supposition that the Afghans are their descendants explains easily and

${ }^{57}$ Sir Alexander Burnes, Travels into Bokhara, 1935: Vol. 2:139-141.

${ }^{58}$ Joseph Ferrier, History of the Afghans. 1858 John Murray. p. 4. Retrieved 14 July 2017.

${ }^{59}$ Sir Alexander Burnes, Travels into Bokhara, 1835 Vol. 2:139-141.

${ }^{60}$ Henry George Raverty, A Grammar of the Pukhto, Pushto, or Language of the Afgháns: together with translations from the articles of war, \&c., and remarks on the language, literature, and descent of the Afghán tribes. 1855. 
naturally both the disappearance of the one people, and the origin of the other. In regard to the men of Mecca he cites... that the principal division of them bore the appellation of Khyber, which is still the name of a district in Afghanistan." (emphasis added). ${ }^{61}$

Colonial-era writing, both in the Muslim world and in Europe is characterized by employing the power of the written word for self-promotion, advocacy, and the promotion of cultural and ideological perspectives rather than by impartial objectivitya clear implication that history was being written more as a story and less as historiography. Didn't Burnes know that claiming to have stated a tradition precisely doesn't make it so and doesn't make it historical? Didn't Raverty have the knowledge that Cyrus who did a favor to the Jews by helping them return to Jerusalem could not at the same time punish them by sending them in the opposite direction? Didn't Elphinstone understand that easily and naturally is nothing more than a rushed conclusion on a coincidence without evidence?

In a tittle-tattle of switching cognates, without sufficient research into the past of Pactyans or Pakthas instead of Afghana, the hasty conclusions of these 'scholars' saw Afghans as 'a people without a known past' that were conveniently matched to 'a people without a known present,' i.e. the lost tribes of Israel. Thus, a mythical narrative was woven out of the threads of falsified history. ${ }^{62}$

\footnotetext{
${ }^{61}$ Elphinstone, as quoted in Sir Olaf Caroe, The Pathans: 550 B.C. - A.D. 1957. Oxford University Press. 1958.

62 This erroneous assumption isn't very different from "a land without a people for a people without a land," the oft-cited phrases in Zionist literature that deny the Palestinians their identity and history. Incidentally, that phrase too harkens back to the same colonial times when in 1843 the Scottish clergyman Alexander Keith, an advocate of the return of Jews to Jerusalem, for the sake of the literal
} 
Sir Olaf Caroe, the British Viceroy's Foreign Secretary and his sixty years of acquaintance with the Pashtuns, in his famous work 'The Pathans,' points to several inconsistencies in these claims, some of which I've incorporated in the following:

\section{A. Claims of Pashtun Jewish Ancestry:}

- "The sons of Afghana withdrew after the captivity, some to the mountains of Ghor in the centre of what is now Afghanistan, and some to the neighbourhood of Mecca in Arabia."

- Afghana, the grandson of King Saul was the chief commander of the army in Solomon's reign, at the time of the Jewish captivity. Khalid bin Walid belonged to the tribe of the descendants of Afghana who resided near Mecca.

- Khalid bin Walid sent a letter to his kinsmen of the Bani Israel settled in Ghor, inviting them to Islam. As a result, a number of representatives of the Afghans of Ghor, led by one Qais, meet the Prophet at Medina. The Prophet remarks that Qais was a Hebrew name and gives Qais the name of Abdur Rashid and confers upon him the title of Pathan. Qais is said to be a descendant from Saul in the thirty-seventh generation.

\section{B. Exposing the Inconsistencies of the Claims:}

fulfillment of the biblical prophecy, linked Jews and Jerusalem as "a people without a country; even as their own land, as subsequently to be shown, is in a great measure a country without a people. Alexander Keith 1843: p. 43. The Land of Israel According to the Covenant with Abraham, with Isaac, and with Jacob (Edinburgh: William Whyte and Co.). 
(1) The first Arab commander who crossed the Euphrates and passed by Ghor on his way to Central Asia was Qutaiba at the end of the seventh century. That was almost seventy years after the time of Khalid.

(2) Khalid bin Walid was not Jewish, but of the Banu Makhzum family, one of the three prominent clans of the Quraysh Arab tribes of Mecca.

(3) How was it even possible for the Afghans in Ghor and Khalid bin Walid in Medina to be communicating and traveling unhindered across the belligerent Sassanid Persia in between?

(4) Qais is not a Jewish name and the Prophet had to have known that.

(5) It would have taken 68 generations from Saul to Qais in order for the latter to have been a descendant of Saul in the thirty-seventh generation. That would've been possible only if everyone in the descending lineage lived over the age of 90 and did not have children until the age of 65 to span the seventeen centuries between them.

(6) The Prophet could not have confirmed the name Pathan on a certain Abdur Rashid because Pathan is a Hindi corruption of the name Pakhtun/Pashtun that came into usage in India nearly 600 years after the time of the Prophet. Besides, the Prophet could not have even pronounced such a name with two non-existent phonemes in Arabic, /p/ and / T/ — a retroflex stop common only in South Asia languages.

(7) The name Afghan (plural Afaaghena) was used only for the Pashtuns in the vicinity of Koh-e Suliman since the publication of Hudood-ul 'Alam in 993CE and not for all Pashtuns. The blanket application of the name Afghan for all Pashtuns such as the Pashtuns in Ghor was a generalization of later centuries. 
(8) If Pashtuns were Jews, how was it even possible that during the entire twelve hundred years from the Babylonian captivity to the rise of Islam, not a single word of Hebrew language or of Jewish tradition was retained by the Pashtuns of Ghor? It is even more improbable considering the equally strong bond and affinity of Pashtuns to their language Pashto and to the lore of Pashtunwali.

\section{Cultural Identity}

Pashtuns have historically been identified as having a knack for a pastoral lifestyle that gives them the ability and mobility to adapt to the frequent winds of change-environmental and political. A dyed-in-the-wool kind of lore-bonding immersed in a code of honor and chivalry encapsulated in Pashtunwali is the medium of a vibrant Pashtun cultural identity—a distinction lost on most other Eastern Iranian or Aryan people in the region.

Pashto is a direct descendant of the Avestan - the hymnal, and liturgical language of Zend-Avesta of the Zoroastrian tradition. As the most dominant of the Eastern Iranian group of the Indo-European family of languages it's the centerpiece of the Indo-Iranian ethnolinguistic mosaic of Central Asia.

Pashtuns have remained politically and numerically strong throughout history and have for centuries been the military backbone of numerous ruling dynasties in Southwest Asia and the Indian Subcontinent such as the Ghaznavids and the Mughals. No Aryan ethnic group has challenged the Turko-Mongol political power monopoly in the region the way the Pashtuns have: From the Ghori, Khalji, Lodi, and Suri dynasties that ruled intermittently between 1186-1545 to the Roshania (Kanigrurm) and Khattak (Akora) principalities in the Pashtun heartland challenging the Mughals to the Hotaki 
and Abdali principalities in Kandahar and Herat respectively that challenged and brought down the Safavids of Persia culminating in the Hotaki rule over Persia between 1722-1729 all the way to the Hotaki, Sadozai/Abdali, and Muhammadzai dynasties that have ruled over Afghanistan since 1709.

This abbreviated historical sketch shows that the fierce and vibrant character and political savvy of Pashtuns is not the description of a people who could be easily coerced into totally giving up their native language and culture.

From a cultural perspective too, the Pashtuns have been very resilient. They have adopted different religions at different times in their history such as Zoroastrianism, Buddhism, or Islam, but they've always held on to their linguistic identity. So much so that in the evolutionary sense modern Pashto is only one step away from Old Avestan and still retains some of the most archaic syntactical characteristics and phonemic clusters. Modern Persian (Dari/Farsi/Tajiki) by comparison has evolved from Pahlawi/Ashkani or Middle Persian which itself has stemmed from Old Persian or Fors-e Qadim, and has thus become much more different and distant from its protoforms.

Jews in the diaspora have also been very protective of their heritage. They may have adopted other languages such as Ladino, Yiddish, Arabic, Aramaic, Persian variations of Judeo-Spanish and Judeo-Arabic and forms of pidgin, creole, diglossia, and digraphia, but these languages have always had a heavy dose of the Hebrew cognates in them. Besides they have always held on to Hebrew as a liturgical 
language ${ }^{63}$ and the Yemenite Jews even held on to their Hebrew throughout the centuries. ${ }^{64}$

If Jews could hold on to their linguistic traditions one way or another as threatened minorities, why is there no trace of their language in Pashto in the form of pidgin, creole, diglossia, or digraphia when Pashtuns have enjoyed numerical strength and political stability.

There have obviously been exceptions to this norm in both communities. Just as there are versions of reformed Judaism and trends of secularism/atheism that may not comply with traditional Judaism, there have been variations of the coercive, assimilative, or adoptive nature with minority and fringe groups of Pashtuns on the fringes of the Pashtun heartland as well that stand as exceptions to the rule.

What is obvious, however, is that in no instance of Pashtun history or for that matter in the anthropological past of any linguistic community, have any people changed their language so thoroughly, so completely and so profoundly that it has not left any syntactical, semantic, or phonetic trances of their original vernacular in their adopted language. This is even less likely to have occurred in languages that belong to two totally different language families such as the Semitic and Indo-European as is the case here. Furthermore, the resilience of Pashtuns trying to hold on to their linguistic and cultural traditions is such that in the course of nearly 13 centuries Pashto has been infused with Arabic/Islamic vocabulary to a far lesser degree than its cultural counterparts, i.e. Dari Persian in Afghanistan and Urdu in Pakistan.

\footnotetext{
${ }^{63}$ Chaim Rabin, A Short History of the Hebrew Language, Jewish Agency and Alpha Press, Jerusalem, 1973.

${ }^{64}$ Aaron Bar-Adon, The Rise and Decline of a Dialect ---- A Study in the Revival of Modern Hebrew, 1975.
} 
In light of this background, one would have to make too many linguistically implausible assumptions in order for the claims of the Jewish ancestry of Pashtuns to make sense:

(1) All Pashtuns would have somehow just forgotten their Semitic Hebrew language and would have adopted a totally different and syntactically and phonologically more complicated language instead.

(2) In order for this to have happened, there must have been some political or religious coercion that would have threatened their cultural survival.

(3) In order for this second assumption to have been true, Pashtuns would have to have been numerically, politically, and militarily so weak that they had no choice but to surrender their civil and human rights and liberties and adopt the language of their oppressors.

(4) And in order for all of these to have happened, Pashtuns would have to have adopted a foreign language so thoroughly and systemically that every Pashtun young and old had to have erased from their memory any trace of the Hebrew language such as shared cognates, social expressions, religious terminologies.

This resilience in holding on to language identities and cultural traits by Pashtuns and Jews is so pronounced and fundamental that they simply could not have given up their Jewish values and adopted Pashtuns ones so easily and thoroughly.

\section{Genographic Evidence}


We can authenticate our claims and hypothesis through strict adherence to the norms of research methodology, which I believe we've done. However, we can go beyond that to support our argument with more certainty.

\section{A. DNA Analysis of the Pashtuns}

The Genographic Consortium study explores the emergence of ethnic groups and how cultural evolutions and technological developments in human history have influenced modern population structures. One such study has focused on four major ethnic groups in Afghanistan including the Pashtuns and has provided convincing DNA evidence that Pashtuns and Tajiks are ethnically Eastern Iranian or Indo-Iranian while the Hazaras and Uzbeks are of the Turco-Altaic origin.

The study, using 52 binary markers and 19 short tandem repeats on the nonrecombinant segment of the Y-chromosome on a total of 204 Afghan samples along with more than 8,700 samples from surrounding populations has concluded convincingly that, "all current Afghans largely share a heritage derived from a common unstructured ancestral population" that could have emerged during the Neolithic 
revolution and the formation of the first farming ${ }^{65}$ communities." ${ }^{96}$ More detailed DNA analysis in this regard shows the strong link of Pashtuns with Tajiks as Eastern Iranian that sets them apart from the Turanian ${ }^{67}$ Uzbeks and Hazaras: "The Afghan Pashtun and Tajik are closer to North and West Indians than to the other Afghans; Hazara and Uzbek. This cluster also sits between East Europeans and Iranians closer to the Iranians especially to East Azerbaijan." ${ }^{68}$

Furthermore, a recent paper titled "The Genomic Formation of South and Central Asia," authored by 92 scientists from around the globe from Harvard, MIT... ${ }^{69}$

\footnotetext{
${ }^{65}$ In the height of European cultural chauvinism when the word 'Aryan' gained recognition in Europe especially, under the influence of Nazi Germany, the word 'Aryan' was interpreted to connote nobility. If
} linguistic norms are any indication, however, 'Aryan' is more closely aligned semantically with settlers in farming communities than a class of nobility since the prefix ar- of Aryan and its related cognates as in Arghandab, Arghanday, Aryoub, Arnawa, Arghistan... are all names of places with large cultivable parcels of land with farming communities. These are not urban centers where the nobility generally resides.

${ }^{66}$ Haber M, Platt DE, Ashrafian Bonab M, Youhanna SC, Soria-Hernanz DF, et al. 2012 Afghanistan's

Ethnic Groups Share a Y-Chromosomal Heritage Structured by Historical Events. The Genographic Consortium. PLoS ONE 7(3): e34288. doi:10.1371/journal.pone.0034288

${ }^{67}$ The terms Turan and Turanian are the historical competitive counterparts of the terms Iran and Iranian in the traditional use of the words in the region. Modern scholarship, at least in linguistics, identifies the people as Turco-Altaic which includes Turco-Mongolian.

${ }^{68}$ Marc Haber, et al. Afghanistan's Ethnic Groups Share a Y-Chromosomal Heritage Structured by

Historical Events. The Genographic Consortium. Published: March 28, 2012.

${ }^{69}$ Other participating scientists were from the Russian Academy of Science, the Birbal Sahni Institute of Paleosciences in Lucknow, the Deccan College, the Max Planck Institute, the Institute for Archaeological Research in Uzbekistan and the Centre for Cellular and Molecular Biology, Hyderabad. Among the co-directors of the study is the Harvard geneticist David Reich. 
Concluded that based on their DNA the people of the Indus Valley next to where the Pashtuns live have been "Iranian agriculturists, who were known to have come to the subcontinent, possibly bringing certain forms of cultivation of wheat and barley with them...(and) the Steppe pastoralists, the inhabitants of the vast Central Asian grasslands to the north of Afghanistan, who were previously known as "Aryans."70

It is possible for the Indo-Iranian Pashtuns to have traces of the DNA of the Greeks, Arabs, Turks, Mongols... and other invading and migrating people who have crisscrossed their lands, but to claim their entire ancestry to be geographically transplanted and culturally transformed from a single 'lost' tribe of Israel is farfetched. It is even more preposterous to ponder this question: How is it possible that the single lost tribe of Israel would prosper, dominate political power in what is today's Iran, Afghanistan, Pakistan, India, and portions of the Central Asian republics and, in spite of the inevitable heavy loss of life in the many wars they fought, their population increases ten times more than all the other eleven tribes of Israel combined?

\section{B. DNA Analysis of the Jews}

Research methodology demands that terms be defined and variables established before a hypothesis can be considered scientific and credible. In respect to this challenge, one such method was undertaken by Haifa's Technion - Israel Institute of Technology that under the auspices of Prof. Karl Skorecki DNA-tested the Mizo-ChinKuki claim of Jewish ancestry and "found no genetic evidence of Middle-Eastern

${ }^{70}$ Rohan Venkataramakrishnan, Who was here first? A new study explains the origins of ancient Indians. QuartzIndia. April 2, 2018. 
ancestry for men." 71 There was also the claim of the Bnei Menashe, the Jews of Manipur, India thousands of whom claimed Jewish ancestry and were settled in Israel. But then "In 2003-2004 DNA testing showed that several hundred men of this group had no evidence of Middle Eastern ancestry."72

In view of these bogus claims, it is necessary that for any assertion of Jewish ancestry to be considered legitimate and scientifically valid, it must meet the following criterion:

(1) A verifiable normative genetic makeup of Jews in the $21^{\text {st }}$ century must be established.

(2) Present-day Jewish DNA must be determined.

(3) This test of Jewish ancestry must be applied to all claimants, including Talmudic Jews.

(4) Only then should one venture into hypothetical remote possibilities such as the assertion that Pashtuns are the lost tribe of Israel.

One reason some might be shying away from such a challenge is the ideological trend in Israel that deliberately overlooks the ethnic origin of the Ashkenazi and East European Jews who, as the likely descendants of the Khazar Turks of Khazaria, ${ }^{73}$ are

\footnotetext{
${ }^{71}$ Isaac L. Hmar, The Lost and Found Jews in Manipur and Mizoram. 2005.

72 Asya Pereltsvaig, Controversies Surrounding Bnei Menashe, June 9, 2010. Israel ‘temporarily’ halted their immigration ion 2004. Later investigation showed that they had been animists practicing ritual headhunting who turned to Messianic Judaism in the late $20^{\text {th }}$ century. https://www.languagesoftheworld.info/geolinguistics/controversies-surrounding-bnei-menashe.html

${ }^{73}$ A member of a Turkic people who occupied a large part of southern Russia from the 6th to the 11 th centuries and who converted to Judaism in the 8th century.
} 
Talmudic Jews and therefore are themselves not the Semitic descendants of Abraham. This idea was first proposed with convincing evidence by Benjamin Freedman ${ }^{74}$ in his 1961 speech, and his subsequent writings, ${ }^{75}$ and has been validated by more recent research.

In his search for the origin of the place name Ashkenaz that occurs three times in the Bible, Eran Elhaik's Geographic Population Structure (GPS) tool, aimed at the largest genomic study of Ashkenazic Jews, ${ }^{76}$ that homes in on north-east Turkey where four primeval villages Iskenaz, Eskenaz, Ashanaz, and Ashkuz are found. ${ }^{77}$

When in the $7^{\text {th }}$ century Khazaria expands into the Caucasus, Ukraine, Russia and Eastern Europe, it becomes "one of the foremost trading emporia of the medieval world"78 "commanding the western marches of the Silk Road and playing a key commercial role as a crossroad between China, the Middle East and Kievan Rus."79

${ }^{74}$ Benjamin Freedman, Speech at the Willard Hotel, 1961. https://www.youtube.com/watch?v=HhFRGDyX48c

${ }^{75}$ Benjamin Freedman Ashkenazi Khazars Self Style "Jews” Are Not Semitic And Not The Biological Descendants of The 12 Tribes of Israel! 1961.

76 There is an implied affirmation of this in the referenced DNA analysis linking the Yiddish language with the Ashkenazic in the Khazar empire: "In the largest genomic study of Ashkenazic Jews, and the first one to study Yiddish speakers," Elhaik writes, "we applied our Geographic Population Structure (GPS) tool... to the genomes of more than 360 Yiddish and non-Yiddish speaking Ashkenazic Jews."

${ }^{77}$ Eran Elhaik. Uncovering Ancient Ashkenaz - the birthplace of Yiddish speakers. 2016. http://theconversation.com/uncovering-ancient-ashkenaz-the-birthplace-of-yiddish-speakers-58355

${ }^{78}$ S. Thomas, "European Russia c500-c1050." Noonan, In Reuter, Timothy; McKitterick, Rosamond, The New Cambridge Medieval History: Volume 3, C.900-c.1024. 3. Cambridge University Press. 1999: pp. $485-534$.

${ }^{79}$ Peter Benjamin Golden, Central Asia in World History. Oxford University Press. 2011. p. 65. 
"By the 8th century the words "Jew" and "merchant" were practically synonymous, and it was around this time that Ashkenazic Jews began relocating from ancient Ashkenaz to the Khazar Empire to expand their mercantile operations.

"This Jewish migration led to some of the Turkic Khazar rulers and numerous eastern Slavs living within the Khazar Empire to convert to Judaism so they didn't miss out on the lucrative Silk Road trade between Germany and China." $" 80$

The Ashkenazi, Sephardic, and Talmudic Jews have as much right to a DNAverified claim to the land as do the Palestinians who as the most persistently long-term inhabitants of the land were Jews who later converted to Christianity and subsequently to Islam. As Syarif Hidayat points out, "Zionist Jews are not descendants of Abraham, Palestinians are! ${ }^{81}$ Applying God's Covenant with Abraham as proof of entitlement to the land, which has no prerequisite of adherence to any particular religion or ideology, demands that his progeny be correctly identified through a DNA test and not necessarily adherence to Judaism or Zionism through the incentive of subsidized colonialism.

\section{Conclusions}

Those whose sense of pride and prejudice is determined by what runs in their veins rather than what fills their perceptions define their humanity ethnically. Others may find this an insult to their dignity.

\footnotetext{
${ }^{80}$ Eran Elhaik, Uncovering Ancient Ashkenaz - the birthplace of Yiddish speakers. 2016.

${ }^{81}$ Syarif Hidayat, Zionist Jews Are Not Descendants of Abraham, Palestinians Are! November 10, 2014.
} 
The 'mythified' misconception that the Pashtuns are the descendants of the lost tribes of Israel is a fabrication popularized in $14^{\text {th }}$-century India. A claim that is full of logical inconsistencies and historical incongruities, and stands in stark contrast to the conclusive evidence of the Indo-Iranian origin of Pashtuns supported by the incontrovertible DNA sequencing that the genome analysis revealed scientifically.

While the search for the lost tribes of Israel may be a worthwhile endeavor for some zealots in Israel, the claim of Jewish descent for Pashtuns is a dangerous adventure. Not just because the claim does not stand a chance of meeting the rigors of scientific inquiry supported by historical, anthropological, linguistic, political, and cultural analysis, but because raising this controversial issue in times of the current political turmoil — the ethnolinguistic sensitivities in Afghanistan and the political unrest in Pakistan - only adds fuel to the fire of a deadly civil strife that has engulfed the two countries for decades contributing to further political instability in the region. For this reason alone, the timing of this mere vicious venture of wishful thinking is reckless, foolhardy, and irresponsible.

When ethnic racism eclipses the human race, ideology wins over identity. Had that not been the case, they could've started the search for the 'lost' tribe of Israel right behind what the Palestinians call the apartheid wall where the true descendants of Abraham might be picking olives. In this realization, re-examination, and re-thinking lies the possibility of a solution to the Middle East's most existential problem, the Israel/Palestine conflict, and the possibility of a lasting peace.

\section{Bibliography:}

Anthony, David W. The Horse the Wheel and Language. How Bronze-Age Riders from the Eurasian Steppes Shaped the Modern World. Princeton University Press. 2007. 
Bar-Adon, Aaron. The Rise and Decline of a Dialect ---- A Study in the Revival of Modern Hebrew. 1975.

Beckwith, Christopher I. Empires of the Silk Road: A History of Central Eurasia from the Bronze Age to the Present. Princeton University Press. 2009.

Beta.Moshiach. Pathans As the Descendants of the Lost Tribes of Israel. (Online - Retrieved October 8, 2020): http://beta.moshiach.com/tribes/pakistan.html

Bhandarkar, D. R. "Mandala 7 of the Rigveda Some Aspects of Ancient Indian Culture."

Biddulph, C. (Trans.). Afghan Poetry of the 17th Century: Selections from the Poems of Khushal Khan Khattak, "Extract from "Passion of the Afghan" by Khushal Khan Khattak." London. 1890.

Burnes, Sir Alexander. Travels into Bokhara. 1935. Vol. 2.

Caroe, Sir Olaf. The Pathans: 550 B.C. - A.D. 1957. Oxford University Press. 1958.

Cunningham, Sir Alexander. The Ancient Geography of India. 1871.

Dani, Ahmad Hasan. "Timargarha and Gandhara Grave Culture.” Ancient Pakistan: Volume 3, University of Peshawar. Dept. of Archaeology - 1967.

Devare, T. N. A Short History of Persian Literature; at the Bahmani, the Adilshahi, and the Qutbshahi Courts. Poona: S. Devare. 1961.

Egorova, Yulia and Shahid Perwez. The Children of Ephraim: Being Jewish in Andhra. Anthropology Today Vol. 26, No. 5, December 2010.

Elhaik, Eran. Uncovering Ancient Ashkenaz - the birthplace of Yiddish speakers. 2016.

Emerson Kent. Com. History for the Relaxed Historian.

http://www.emersonkent.com/map archive/oriental empires 600 bc.htm

Ferrier, Joseph-Ferrier. History of the Afghans. 1858. Retrieved 14 July 2017.

Firištah, Muhammad Qāsim Hindū Šāh Astarābādī. History of the Mohamedan Power in India 15601620.

Fischer, Steven R. A History of Writing. London: Reaction Books. 2004. ISBN 1-86189-101-6. 
Freedman, Benjamin. Ashkenazi Khazars Self Style "Jews" Are not Semitic and not the Biological Descendants of the 12 Tribes of Israel! 1961.

Freedman, Benjamin. Speech at the Willard Hotel, 1961. https://www.youtube.com/watch?v=HhFRGDyX48c

George, Arthur (Trans.). The Shahnama of Firdausi. The Persian Book of Kings, by Abolqasem Firdausi. 1010.

Golden, Peter Benjamin “Central Asia in World History.” New Oxford World History. Oxford University Press. 2011. ISBN 978-0-19-979317-4.

Haber, Marc, et al. “Afghanistan's Ethnic Groups Share a Y-Chromosomal Heritage Structured by Historical Events. The Genographic Consortium. Published: March 28, 2012.

Habibi, Abdul Hai. “Afghan and Afghanistan.” Afghanistan, VOL. XXII No.2, Summer 1348 (1969). alamahabibi.com. Retrieved 2010-10-24.

Habibi, Abdul Hai. Archeological Recollections. Printed in Shiraz. 1959: Vol. IV.

Hidayat, Syarif. “Zionist Jews Are Not Descendants of Abraham, Palestinians Are!” November 10, 2014.

Hmar, Isaac L. "The lost and found Jews in Manipur and Mizoram." (This article was webcast on April 21 st, 2005).

Hutchinson's History of the Nations. "The Forenoon of Life - Aryans Entering India, 3500 B.C." illustration. C. 1910 .

Ibn Battuta. Travels in Asia and Africa, 1325-1354. (reprint, illustrated ed.) Routledge. 2004. ISBN 0415-34473-5.

Jackson, Peter. The Delhi Sultanate: A Political and Military History. Cambridge University Press. Retrieved 2009-02-20.

Nath, Samir. Dictionary of Vedanta. Sarup \& Sons. 2002.

Naweed, Hamid. Art Through the Ages in Afghanistan. Authorhouse. 2018. passim. ISBN: 1477265759 EAN13: 9781477265758. 
Noonan, Thomas S. "European Russia c500-c1050." In Reuter, Timothy; McKitterick, Rosamond. The New Cambridge Medieval History: Volume 3, C.900-c.1024. 3. Cambridge University Press. 1999.

Ovadiah, Rabbi of Bartenura. "Pathway to Jerusalem: The Travel Letters of Rabbi Ovadiah of Bartenura: Written Between 1488-1490 During His Journey to the Holy Land." 1992.

Pereltsvaig, Asya. Controversies Surrounding Bnei Menashe, June 9, 2010. https://www.languagesoftheworld.info/geolinguistics/controversies-surrounding-bnei$\underline{\text { menashe.html }}$

Platt, Haber M, DE, Ashrafian Bonab M, Youhanna SC, Soria-Hernanz DF, et al. Afghanistan's Ethnic Groups Share a Y-Chromosomal Heritage Structured by Historical Events. The Genographic Consortium. PLoS ONE. 2012. 7(3): e34288. doi:10.1371/journal.pone.0034288.

Rabin, Chaim. A Short History of the Hebrew Language. Jerusalem: Jewish Agency and Alpha Press. 1973.

Rashid, Salman. Pakhtuns. Published in The Express Tribune, November 12 $2^{\text {th }}, 2011$. https://tribune.com.pk/story/290251/pakhtuns

Raverty, Henry George. A Grammar of the Pukhto, Pushto, or Language of the Afgháns. (together with translations from the articles of war, \&c., and remarks on the language, literature, and descent of the Afghán tribes). 1855.

Rawlinson, George (Trans.). "The History of Herodotus Chapter 7, Written 440 B.C.E.". Piney.Com Library of Biblical and Historical Documents. Retrieved 2020-04-09.

Rosen, Moses. “The Recipe: published as an epilogue to The Face of Survival.” 1987.

Schwartzberg, J. E. A Historical Atlas of South Asia. University of Oxford Press Staal, F. (2008) 1992.

Scottish Geographical Magazine. Royal Scottish Geographical Society. 1999.

Sperling, S. David (2nd ed.). Medes and Media. Encyclopaedia Judaica Jewish Virtual Library (Online). http://www.jewishvirtuallibrary.org/medes-and-media

Subhash, Kak, "On the Chronology of Ancient India." Indian Journal of History of Science. 1987 (22): 222-234. Archived from the original (PDF) on 2015-01-22. Retrieved Jan 2015.

The Bible 2: Kings 17:5-23. Bible verses for: 'Lost' Ten Tribes of Israel. 
The Encyclopædia Britannica https://www.britannica.com/search?query=Tiglath-pileser+III

Venkataramakrishnan, Rohan. Who was here first? A new study explains the origins of ancient Indians. QuartzIndia. April 2, 2018.

Violatti Cristian, Aryan. The Ancient History Encyclopedia. Published 06 April 2018.

Weil, Shalva, The Israelite Connections of the Taliban - By Shalva Weil for ISN Insights. Africa News Analysis. 08/09/2011 (Online) https://www.africanewsanalysis.com/the-israelite-connections-ofthe-taliban-by-shalva-weil-for-isn-insights/

Yari, Avraham. "Igros Eretz Yisroel (Letters of the Land of Israel), in the "Letters of Rabbi Obadiah di Bertinora from Jerusalem to his Brother," written in 1489, Tel-Aviv. 1943. 